\section{Yersinia and chronic glomerulopathy in the savannah region of Nigeria}

Glomerular disease secondary to Yersinia enterocolitica infection is well recognised in some parts of the world. ${ }^{12}$ It has been suggested ${ }^{3}$ that the glomerulopathy from this infection might progress to chronic glomerulopathy. In this study, which formed part of an investigation into the pattern of glomerular disease in the savannah belt in Nigeria, we investigated the association between $Y$ enterocolitica and chronic glomerular disease.

\section{Patients, methods, and results}

Twenty-three patients (13 male, 10 female) aged 12-55 years admitted with the nephrotic syndrome (oedema, hypoalbuminaemia, and proteinuria of over $0.5 \mathrm{~g} / \mathrm{kg}$ body weight $/ 24 \mathrm{~h}$ ) had their sera tested for agglutinating antibodies against $Y$ enterocolitica 0 serotypes 3,8 , and 9 . The agglutination was carried out in test tubes by adding the antigen to serial dilutions (from $1 / 20$ to $1 / 320$ ) of the sera prepared in $1 \mathrm{ml}$ amounts. Antibodies were regarded as being present at titres of $1 / 40$ and over. All seropositive patients were tested for brucella agglutinins and for evidence of recent streptococcal infection. Renal biopsy was done in all 23 cases. Twenty-four patients with chronic non-glomerular disease and 20 normal subjects matched for age, sex, occupation, and area of residence served as controls. All tests for agglutinating titres were done blind.

The table shows the histological type of disease in 20 of the patients and their $Y$ enterocolitica antibody titres to the three 0 serotypes. None of the controls had yersinia antibodies, and none of the seropositive patients had antibodies to Brucella.

Details of patients and titres of antibodies to $Y$ enterocolitica

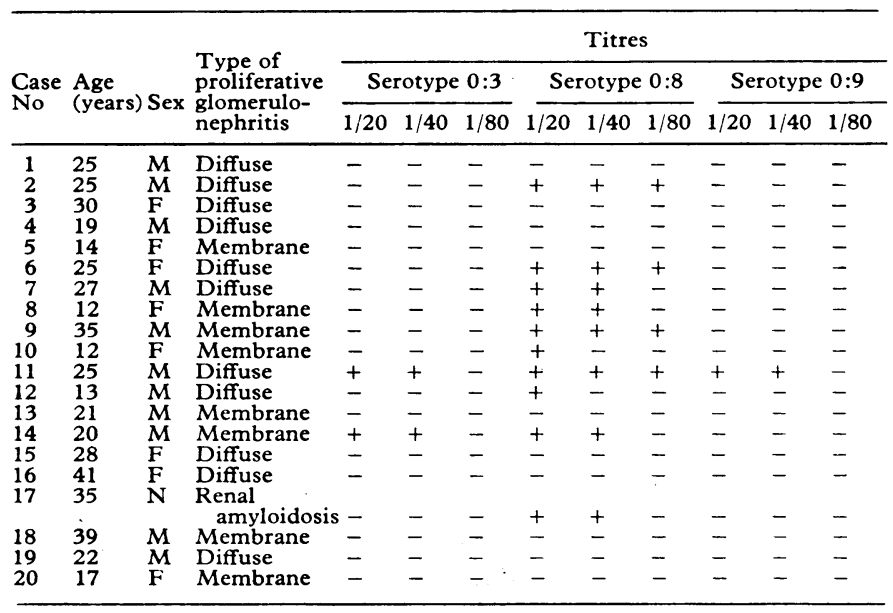

\section{Comment}

Ten of the 23 patients studied showed evidence of previous $Y$ enterocolitica infection. None of these seropositive patients could give a history indicative of definite past yersiniosis. Symptoms of yersiniosis, however, such as fever, diarrhoea, and abdominal pain, are non-specific and common in the tropics. No patient had ever had a septicaemic illness, arthritis, or erythema nodosum. Possibly they had sub-clinical infections. $Y$ enterocolitica may lead to acute glomerulonephritis. ${ }^{24}$ In a study we did of acute glomerulonephritis in adults only one in 16 patients showed evidence of antecedent streptococcal infection. Possibly some of these cases may have been due to yersiniosis and may progress to chronic nephritis in future.

This is the first time yersiniosis has been reported from the tropics and in relation to chronic glomerulopathy. Immunological investigations will be necessary to obtain more direct evidence of a connection between glomerulopathy and yersiniosis. Infection with 0 serotype 8 has previously been reported only in the USA. It appears from our study that 0 serotype 8 causes most infection and is possibly nephrotoxic; in Scandinavia 0 serotype 3 predominates.
We thank Dr N Mair of the Public Health Laboratory, Leicester, England, for supplying the yersinia antigens.

${ }^{1}$ Leino R, Kalliomaki JK. Yersiniosis as an internal disease. Ann Intern Med $1974 ; 81: 458-61$.

${ }^{2}$ Friedberg $M$, Denneberg T, Larsen S. Yersinia enterocolitica and glomerulonephritis. Lancet 1978; ; :498-9.

${ }^{3}$ Friedberg M, Denneberg T, Brun C, Larsen JH, Larsen S. Glomerculonephritis in infections with Yersinia enterocolitica 0-serotype 3. II. The evidence and immunological features of yersinia in a consecutive glomerulonephritis population. Acta Med Scand 1981;209:103-10.

- Denneberg T, Friedberg M, Samuelson T, Winblad S. Glomerulonephritis in infections with yersinia enterocolitica 0 -serotype 3 . I. Evidence for glomerular involvement in acute cases of yersiniosis. Acta Med Scand $1981 ; 209: 97-101$.

(Accepted 24 August 1982)

Department of Medicine, Ahmadu Bello University Teaching Hospital, Zaria, Nigeria

C AWUNOR-RENNER, MRCP, consultant physcian (present address: Medical Unit, Southland Hospital, Kew, Invercargill, New Zealand)

Department of Medical Microbiology, Ahmadu Bello University, Zaria, Nigeria

R V LAWANDE, MD, senior lecturer

\section{Popular marathons: forecasting casualties}

More than 100 open-entry long-distance running events are planned in Britain this year. ${ }^{1}$ We report on the nature and volume of casualties that occurred in the 1982 Sheffield marathon: these data may help in planning supporting medical services for such events.

\section{Methods and results}

Medical students recorded clinical details of all contacts made by runners with any of the 12 first-aid posts along the 26.2 mile $(42 \mathrm{~km})$ route of the 1982 Sheffield marathon, which had an option of running only half the distance (half marathon).

A total of 4559 ( 4277 men, 282 women) submitted entry forms, giving their age, sex, previous marathon experience, and the distance they intended to cover (half or full marathon). Of these, only $3462(76 \%)$ subsequently registered for the start of the race. The "no show" proportions were not related to sex, previous experience, or distance intended, but significantly more over- 40 s $(82 \%)$ registered than younger entrants $(75 \%)(p<0.05)$.

Of those who registered, 2602 specified their intention of running the full marathon, but $494(19 \%)$ of these finished at the halfway stage. A total of 825 entrants intended to complete only half the distance, but $181(22 \%)$ ᄋ went on to complete the full marathon. Completing a distance different $₹$ from that originally intended was related to previous experience: experienced runners ran further than intended less often than inexperienced runners did, and more often ran a shorter distance. Data on the intention of the remaining $\mathrm{N}$ 35 runners were unavailable.

Of the 2289 who ran the full marathon (all those who ran beyond the halfway stage) $409(18 \%)$ made 580 contacts with first-aid stations, presenting 672 first-aid problems. Of 1140 who ran a half marathon (all those who $\mathrm{N}$ finished at this point or who did not reach it), $41(4 \%)$ made only 46 contacts, presenting 49 first-aid problems: these are not considered further. Of those $\mathrm{\omega}$ completing the full marathon who made contact there was a significantly higher proportion of women $(32 \%)$ than men $(17 \%)$, and significantly fewer over $40(13 \%)$ than under $(18 \%)$. Those with any previous experience of running had a significantly lower contacting ratio $(14 \%)$ than those without $\mathbb{D}$ $(19 \%)$, and this was true for each age group.

More than half the problems related to muscles or joints (see table). Skin 7 conditions, especially blisters, were the next most common problems. 0 Extreme exhaustion, accompanied in a few cases by mental disturbances, $\overrightarrow{\mathbb{D}}$ was not uncommon. Runners who had completed full marathons before presented relatively fewer. localised problems and more constitutional $\propto$ problems. Most contacts were with the later stations. Only at the finish was there a sizeable proportion of constitutional disorders warranting more intensive treatment. Twenty-six runners $(1 \%)$, all intending to run the full $\delta$ marathon, were taken to hospital, suffering from manifestations of heat illness (24) or leg injuries (two). Four were detained, but they were discharged the next day. 
No $(\%)$ of presenting problems by characteristics of runners $(n=409)$ and location of first-aid stations

\begin{tabular}{|c|c|c|c|c|c|c|c|c|c|c|c|c|}
\hline & $\begin{array}{l}\text { Skin lesion, } \\
\text { including } \\
\text { blisters }\end{array}$ & $\begin{array}{l}\text { Muscle or } \\
\text { joint pain } \\
\text { or stiffness }\end{array}$ & $\begin{array}{l}\text { Nausea, } \\
\text { diarrhoea, } \\
\text { or vomiting }\end{array}$ & $\begin{array}{c}\text { Extreme } \\
\text { thirst }\end{array}$ & $\begin{array}{c}\text { Exhaustion, } \\
\text { mentally } \\
\text { clear }\end{array}$ & $\begin{array}{l}\text { Exhaustion } \\
\text { with } \\
\text { mental } \\
\text { confusion }\end{array}$ & $\begin{array}{c}\text { Cold, } \\
\text { rigor, } \\
\text { hypothermia }\end{array}$ & $\begin{array}{c}\text { Faintness } \\
\text { or } \\
\text { dizziness }\end{array}$ & $\begin{array}{l}\text { Toothache, } \\
\text { earache, } \\
\text { headache }\end{array}$ & Other & Not stated & $\begin{array}{c}\text { Total } \\
(\mathrm{n}=672)\end{array}$ \\
\hline \multicolumn{13}{|c|}{ Runners } \\
\hline $\begin{array}{l}\text { Sex: } \\
\text { Male } \\
\text { Female } \\
\text { Not known }\end{array}$ & $104(16)$ & $\begin{array}{r}372(58) \\
15(50)\end{array}$ & $\begin{array}{r}38(6) \\
3(10)\end{array}$ & $\begin{array}{r}24(4) \\
4(13)\end{array}$ & $\begin{array}{r}55(9) \\
4(13)\end{array}$ & $6(1)$ & $\begin{array}{r}18(3) \\
2(7)\end{array}$ & $\begin{array}{l}8(1) \\
2(7)\end{array}$ & $5(1)$ & $4(1)$ & $6(1)$ & $\begin{array}{c}640(100) \\
30(100) \\
2\end{array}$ \\
\hline \multirow{3}{*}{$\begin{array}{l}\text { Age (years): } \\
\text { 18-29 } \\
30-39 \\
40+ \\
\text { Not known } \\
\text { Previous experience: } \\
\text { None } \\
\text { Half-marathon } \\
\text { Full-marathon } \\
\text { Not known }\end{array}$} & & & & & & & & & & & & \\
\hline & $\begin{array}{r}60(15) \\
31(17) \\
9(12)\end{array}$ & $\begin{array}{r}228(58) \\
103(57) \\
45(61)\end{array}$ & $\begin{array}{r}22(6) \\
12(7) \\
6(8)\end{array}$ & $\begin{array}{r}18(5) \\
9(5) \\
1(1)\end{array}$ & $\begin{array}{c}38(10) \\
13(7) \\
6(8)\end{array}$ & $\begin{array}{l}4(1) \\
1(1) \\
1(1)\end{array}$ & $\begin{array}{r}11(3) \\
5(3) \\
3(4)\end{array}$ & $\begin{array}{l}5(1) \\
3(2) \\
2(3)\end{array}$ & $\begin{array}{l}3(1) \\
2(1)\end{array}$ & $\begin{array}{l}3(1) \\
1(1)\end{array}$ & $\begin{array}{l}3(1) \\
3(2)\end{array}$ & $\begin{array}{c}395(100) \\
182(100) \\
74(100) \\
21\end{array}$ \\
\hline & $\begin{array}{r}74(16) \\
9(13) \\
16(13)\end{array}$ & $\begin{array}{r}281(62) \\
41(61) \\
52(42)\end{array}$ & $\begin{array}{c}20(4) \\
6(9) \\
14(11)\end{array}$ & $\begin{array}{r}16(4) \\
3(4) \\
9(7)\end{array}$ & $\begin{array}{l}35(8) \\
3(4) \\
19(15)\end{array}$ & $\begin{array}{l}2(1) \\
1(1) \\
3(2)\end{array}$ & $\begin{array}{l}9(2) \\
2(3) \\
8(6)\end{array}$ & $\begin{array}{l}7(2) \\
1(1) \\
2(2)\end{array}$ & $\begin{array}{l}4(1) \\
1(1)\end{array}$ & $\begin{array}{l}2(1) \\
1(1) \\
1(1)\end{array}$ & $6(1)$ & $\begin{array}{r}456(100) \\
67(100) \\
125(100) \\
24\end{array}$ \\
\hline $\begin{array}{l}\text { No of miles }(\mathrm{km}) \\
\text { from start: } \\
\leqslant 9(14.5)\end{array}$ & $11(44)$ & $6(24)$ & $1(4)$ & $3(12)$ & First-aid sta & ations contacte & $1(4)$ & & $2(8)$ & $1(4)$ & & $25(100)$ \\
\hline $\begin{array}{l}\leqslant 18(29) \\
20(32) \\
23(37) \\
25(40) \\
26(42) \dagger \\
\text { Following bus }\end{array}$ & $\begin{array}{c}29(32) \\
6(5) \\
9(9) \\
4(5) \\
46(19)\end{array}$ & $\begin{array}{l}55(61) \\
96(81) \\
76(76) \\
60(75) \\
89(36) \\
2\end{array}$ & $\begin{array}{c}1(1) \\
5(4) \\
3(3) \\
2(3) \\
25(10) \\
2\end{array}$ & $\begin{array}{l}1(1) \\
12(15) \\
12(5)\end{array}$ & $\begin{array}{c}1(1) \\
5(5) \\
7(7) \\
2(3) \\
43(18) \\
2\end{array}$ & $5(2)$ & $\begin{array}{r}3(3) \\
16(7)\end{array}$ & $\begin{array}{l}1(1) \\
1(1) \\
7(3)\end{array}$ & $2(2)$ & $1(0)$ & $\begin{array}{l}3(3) \\
3(3)\end{array}$ & $\begin{array}{r}90(100) \\
118(100) \\
100(100) \\
80(100) \\
245(100) \\
7\end{array}$ \\
\hline
\end{tabular}

* Finish of half marathon.

†Finish of full marathon.

\section{Comment}

Entrants were provided with printed advice about training and dietary preparation, and about who should not participate. Onequarter of the entrants did not run: a follow-up inquiry showed that it was not the heat $\left(24^{\circ} \mathrm{C}\right)$ and relative humidity $(82 \%)$ which deterred them. This no-show rate may therefore be typical of such events.

To plan the first-aid and health service facilities, forecasts of the number of casualties among runners have to be based on what is known about the entrants. Working backwards, in a full marathon the higher the proportion of women, young men, and runners without previous experience the greater the number of casualty problems created. Experienced runners give rise to fewer problems than the inexperienced but the problems presented are more often constitutional. For all runners the yield and complexity of problems increases with the distance run.

Half marathons need create only small casualty work loads: moreover, having a half-marathon option in a longer race provides a useful safety valve, which older, more experienced runners will take to a greater extent than the young and inexperienced. A race with 4500 entrants need not provide much additional work load for the health services.

We thank the South Yorkshire branch of the British Red Cross Society, the organising committee of the Sheffield Marathon, and Mr John Whetton, race director, for the facilities to undertake this study.

${ }^{1}$ Anonymous. Marathon update. Running Magazine 1982, June:21.

(Accepted 14 September 1982)

Department of Community Medicine, University of Sheffield Medical School, Sheffield S10 2RX

JONATHAN P NICHOLL, MA, BSC, statistician

BRIAN T WILLIAMS, MD, FFCM, senior lecturer

\section{Methods and results}

Ten days after the race questionnaires were mailed to random samples (after stratification for age, sex, and previous experience) of about one in six of the 3462 runners and the 1097 entrants who failed to register for the start (non-runners). Those not responding after two weeks received reminders and duplicate questionnaires. The response rates were $80 \%$ (147 out of 184 ) for the non-runners and $91 \%$ (557 out of 614) for the runners.

Fifty-two non-runners $(35 \%)$ gave non-medical reasons for withdrawing, including work and family commitments, and $92(63 \%)$ gave medical reasons, including injury in training (19), other injuries (29), decided not fit enough (24), or other health reasons (20). Withdrawal for medical reasons was not related to age or sex. Three non-runners gave no reason. A medical reason was given less often by those who had previously run a full marathon (16 of $37,43 \%$ ) than by those who had run a half marathon (19 of $28,68 \%$ ) or neither distance $(54$ of $74,73 \%)(p<0.05)$. Among those giving medical reasons, injury in training was cited by considerably more men (16 of 68 , $24 \%$ ) than women (two of $21,10 \%$ ): the most common injuries were to knee joints (nine cases) and thigh muscles (eight).

Among the runners, pain, discomfort, or illness in the week after the race was reported by $97(40 \%)$ of those who ran the half marathon and $203(65 \%)$ of those who ran beyond this stage. Four others gave no answer; 10 did not run although they registered for the start. Pain or stiffness in leg muscles affected $130(64 \%)$ of the 203 full-marathon runners who reported problems and $61(63 \%)$ of the 97 with problems after running a half marathon. Next most common were joint problems $(59(29 \%)$ full marathon, $20(21 \%)$ half marathon), with knee joints particularly affected, and blistered feet (30 $(15 \%)$ and seven $(7 \%))$. Other problems were general malaise $(19(6 \%)$ of all 300 with problems), alimentary disorders $(12(4 \%))$ and vertebral column pain $(11(4 \%))$. Four runners caught colds. Most of the disorders were minor. Only 22 runners, $4 \%$ of the sample, consulted a doctor.

Similar proportions of men and women at each distance suffered after effects. Older runners fared as well or better than younger ones, and fewer of those who had run a full marathon before developed problems (see table).

Only 32 days' work were lost in the week after the race by the 467 runners who were in full-time employment. Six of the $300(2 \%)$ white-collar workers needed time off, and 10 of the $157(6 \%)$ blue-collar workers. After effects prevented 36 out of 556 respondents $(6 \%)$ from doing something else of social importance to them, nearly always a form of exercise.

No (\%) of runners reporting medical problems after marathon

\begin{tabular}{|c|c|c|c|c|c|c|}
\hline & \multicolumn{2}{|c|}{ Half marathon } & \multirow[b]{2}{*}{$\underset{\text { Value }}{p}$} & \multicolumn{2}{|c|}{ Full marathon } & \multirow[b]{2}{*}{$\underset{\text { Value }}{p}$} \\
\hline & $\begin{array}{c}\text { No in } \\
\text { sample }\end{array}$ & $\begin{array}{c}\text { No (\%) } \\
\text { reporting } \\
\text { problems }\end{array}$ & & $\begin{array}{c}\text { No in } \\
\text { sample }\end{array}$ & $\begin{array}{l}\text { No }(\%) \\
\text { reporting } \\
\text { problems }\end{array}$ & \\
\hline Total: & 242 & $97(40)$ & & 312 & $203(65)$ & \\
\hline $\begin{array}{l}\text { Sex: } \\
\text { Male } \\
\text { Female } \\
\text { Female }\end{array}$ & $\begin{array}{r}178 \\
64\end{array}$ & $\begin{array}{l}70(39) \\
27(42)\end{array}$ & NS & $\begin{array}{r}283 \\
29\end{array}$ & $\begin{array}{r}186(66) \\
17(59)\end{array}$ & NS \\
\hline $\begin{array}{l}\text { Age (years): } \\
\text { Under } 40 \\
40+ \\
\text { Previous experience. }\end{array}$ & $\begin{array}{r}180 \\
62\end{array}$ & $\begin{array}{l}80(44) \\
17(27)\end{array}$ & $p<0.05$ & $\begin{array}{r}239 \\
73\end{array}$ & $\begin{array}{r}159(67) \\
44(60)\end{array}$ & NS \\
\hline $\begin{array}{l}\text { None } \\
\text { Half marathon } \\
\text { Full marathon }\end{array}$ & $\begin{array}{r}129 \\
63 \\
50\end{array}$ & $\begin{array}{l}59(46) \\
26(41) \\
12(24)\end{array}$ & $\mathrm{p}<0.05$ & $\begin{array}{r}160 \\
35 \\
117\end{array}$ & $\begin{array}{r}114(71) \\
25(71) \\
64(55)\end{array}$ & $\mathrm{p}<0.01$ \\
\hline
\end{tabular}

\section{Medical problems before and after a popular marathon}

We report here data on the medical problems experienced by runners preparing for a marathon, the medical sequelae of participating, the demands for medical care these create, and their effects on the ability to work and to fulfil other social functions. The data were obtained from a sample of the $\mathbf{4 5 5 9}$ entrants for the Sheffield marathon held in June 1982. 